\title{
Clonal propagation of female plants of Garcinia indica Choiss: a tree species of high medicinal value
}

\author{
Swapna Deodhar ${ }^{1}$, Kiran Pawar ${ }^{1,3}$, Nitasha $\operatorname{Singh}^{1}$, R.J. Thengane ${ }^{2}$, S.R. Thengane ${ }^{1 *}$ \\ ${ }^{1}$ Plant Tissue Culture Division, National Chemical Laboratory, Pune - 411008, India. ${ }^{2}$ Department of Botany, University of Pune, Pune - 411008 , India. ${ }^{3}$ \\ Department of Biotechnology, Shivaji University, Kolhapur, Kolhapur- 416004, India.
}

\section{ARTICLE INFO}

Article history:

Received on: 19/02/2014

Revised on: 03/07/2014

Accepted on: 06/09/2014

Available online: 27/12/2014

Key words:

Garcinia indica, Clonal

propagation, medicinal plants.

\begin{abstract}
Fruits of Garcinia indica, a medicinally important tree species from Western Ghats of India is a rich source of medicinally important (-) Hydroxycitric acid that shows anticholesterol and antiobesity activities. Since this species is polygamodioecious, sex of the plant can be identified only after flowering that takes approximately 7-8 yrs. From commercial and horticultural point of view, plantation of female trees is much preferred. In this study, an efficient protocol for propagation of female plants was developed using in vitro techniques. For establishment of sterile cultures, fungal contamination and browning of explants were the major hurdles. Season of plant material collection and culture vessels used for in vitro sprouting were also observed significant factors in establishment of sterile cultures. The use of WPM basal fortified with $2 \%$ sucrose and $8.87 \mu \mathrm{M}$ BAP resulted maximum sterile and healthy buds. TDZ in the range $0.22-4.54 \mu \mathrm{M}$ along with BAP induced multiple shoots. Highest $63 \%$ rooting was obtained on WPM medium with $4.90 \mu \mathrm{M}$ IBA whereas, maximum $60 \%$ plantlets survived in green house after their transfer to soil.
\end{abstract}

Abbreviations: BAP: 6-Benzyl amino purine, TDZ : Thidiazuron ((N-phenyl-N'-1,2,3-thidiazol-5-ylurea), IAA: Indole-3-acetic acid, IBA: Indole-3-butyric acid, IPA: Indole-3-propionic acid, NAA: $\alpha$-Napthalene acetic acid, SDW: Sterile Distilled Water, ANOVA: Analysis of Variance, WPM: Woody Plant Medium.

\section{INTRODUCTION}

Garcinia indica Choiss. (Family Clusiaceae) commonly known as 'Kokum Butter Tree' is an underexploited fruit tree species found in tropical rain forest of Western Ghats of India. Fruits of Garcinia have many remarkable medicinal properties, the most important of which is antiobesity effect. Fruit rind of $G$. indica contains hydroxycitric acid (-)- (HCA) and garcinic acid. (-) HCA being the strong inhibitor of citrate cleavage enzyme is widely used in formulations of antiobesity drug worldwide [1-4]. Beside antiobesity properties, fruits also possesses anthelmintic, cardio tonic and anti-tumour properties and is useful in the treatment of piles and dysentery. Kokum butter, a preparation from fruits is an emollient and is useful in burns, scalds, cosmetics as well as extender in confectionary items [5]. Fruits also contain several active compounds that exhibit biological activities against bacteria [6], diabetes [7] and HIV-1 protease [8].

\footnotetext{
* Corresponding Author

E-mail: sr.thengane@ncl.res.in, Phone No.:091-020-25893300, Fax No.: 091-02025893438
}

Being a tree species, it is slow growing, cross pollinated and polygamodioecious in nature. The differentiation between male and female plants is possible only after flowering stage. Mostly it takes 7-8 years for the plants to bear flower. In horticultural practices, propagation of $G$. indica is generally done by seeds and soft wood grafting [9]. The seeds are recalcitrant due to high sensitivity to desiccation and freezing with shelf life of only 4 weeks [10]. Thus, it becomes difficult to raise seedlings throughout the year. Moreover, in an orchard established with seedlings, 50\% plants are generally male. As reported by various workers, grafting is another method that can be used for clonal propagation of $G$. indica $[11,12]$. The successful clonal propagation of $G$. indica is season dependent, space requiring and moreover grafted plants show change in the canopy with reduced fruit yield, thus has limited applications. Availability of root stock is another limitation for large scale successful grafting.

This medicinally rich plant species is listed as endangered species of Southern India [13], which makes it necessary to conserve this tree species. Conservation of genetic diversity is presently being undertaken on limited scale by maintaining trees in 
situ which is associated with various problems. In vitro conservation and cryopreservation offer the only safe and cost effective option for long term conservation of genetic resources of recalcitrant species such as $G$. indica [14].

Most of the studies on in vitro propagation of genus Garcinia have been conducted in G. mangostana using variety of explants like seed [15], leaves [16] and via nodular callus formation by Te-Chato and Lim [17]. Repetitive somatic embryogenesis from seed explants in G.indica was obtained by Thengane and coworkers [18], while de novo shoot regeneration from root cultures was reported by Deodhar coworkers [19]. A method for regeneration of plantlets via adventitious bud diffentiation from mature seeds of $G$. indica has been developed by Malik et al. [20]. Kulkarni and Deodhar (2002) used immature seeds and young leaves for in vitro production of G.indica plants [21] while Deshpande et al. (1999) and Mathew et al. (2001) conducted preliminary studies on in vitro establishment of kokum apical buds [22,23]. However, no reports are available on in vitro multiplication of female plants of $G$. indica.

In the present study, few female plants with high fruit bearing and HCA content were identified and collected from the different locations in Maharashtra region of the Western Ghats of India and used for clonal propagation. With the aim of clonal multiplication and its conservation, in vitro propagation method for these identified elite plants was standardized using different hormones, antimicrobial agents, additive and in vitro as well as ex vitro rooting.

\section{MATERIAL AND METHODS Plant material}

Apical and axiliary buds of $G$. indica were collected from identified elite female trees in different seasons of the year. Buds were first kept in running water for 1 hour and then washed with labolene (Qualigens, India) as a surfactant followed by washing with $10 \%$ Savlon (v/v) (Johnson and Johnson Ltd, India) as an antiseptic. This was followed by treatments first with $0.1 \%(\mathrm{w} / \mathrm{v})$ polyvinyl polypyrolidone (Sigma, USA) for $30 \mathrm{~min}$ and later by $1 \%(\mathrm{w} / \mathrm{v})$ Bavistin (BASF, India) for $60 \mathrm{~min}$. After each treatment, buds were washed thoroughly with sterile distilled water (SDW). All further operations were carried out in laminar air flow (LAF) chamber under sterile conditions. In LAF, buds were first rinsed with $70 \%$ ethanol (v/v); washed with SDW for 5-6 times. After treatment with $70 \%$ ethanol, buds were treated with $1 \% \mathrm{HgCl}_{2}$ (w/v) (Qualigens, India ) for $7 \mathrm{~min}$. and again washed thoroughly 5-6 times with SDW.

\section{Media preparation}

These surface sterilized buds were then inoculated on Woody Plant Medium (WPM) [24] supplemented with 6benzylamino purine (BAP; $8.87 \mu \mathrm{M}$ ) (Sigma, USA). Medium was fortified with $2 \%$ sucrose (Qualigens, India) and solidified with $0.75 \%$ agar (Qualigens, India) after adjusting the $\mathrm{pH}$ to 5.8-6. All growth regulators were incorporated into the medium before autoclaving. The media were sterilized by autoclaving at $120^{\circ} \mathrm{C}$ for $20 \mathrm{~min}$ at $105 \mathrm{kPa}$. The inoculated cultures were incubated at $25 \pm 1^{\circ} \mathrm{C}$ at $16 / 8 \mathrm{hrs}$ photoperiod with $35 \mu \mathrm{E}^{-2} \mathrm{~m}^{-2} \mathrm{~s}^{-1}$ illumination provided by cool white fluorescent tubes.

Contamination due to fungus was a major hurdle in establishment of sterile cultures. Therefore initially standardization of protocol for obtaining sterile cultures was the first step. To avoid microbial contamination, anti-fungal agent Bavistin alone in concentration range $65-85 \mathrm{mg} / \mathrm{L}$ or in combination with antibiotic Cefotaxim (300 and $500 \mathrm{mg} / \mathrm{L}$ ) (Alkem Laboratories, India) were tested. The effect of additive such as Plant Preservative Mixture (PPM) as antifungal and antibacterial agents on microbial contamination was also tested.

To study the effect of culture vessel was studied by using both, cotton plugged culture tubes and plastic capped jam bottles containing 20 and $80 \mathrm{ml}$ medium respectively. For each medium formulation 20 tubes and 15 bottles were used. Single bud was cultured per vessel and each experiment was repeated thrice. The established sterile cultures were tested for in vitro response on WPM basal medium supplemented with different combinations and concentrations of plant hormones 6-Benzyl Amino Purine (BAP), Kinetin, Indol-3-acetic acid (IAA) and indol-3-butyric acid (IBA).

\section{In vitro Multiplication}

The effect of these hormone on sprouting of buds was studied by supplementing WPM with BAP in the range 4.44-8.8.7 $\mu \mathrm{M}$, kinetin in the range $2.32-4.65 \mu \mathrm{M}$, IAA $5.71 \mu \mathrm{M}$ and IBA $4.90 \mu \mathrm{M}$ either singly or in combination. All the media were fortified with Bavistin (75 mg/L) and Cefotaxim (400 mg/L) along with $2 \%$ sucrose and $0.75 \%$ agar. After 6 weeks, sprouted sterile buds were shifted to WPM containing BAP $(8.87 \mu \mathrm{M})$ with Thidiazuron (TDZ) in the range 2.27-4.54 $\mu \mathrm{M}$ for multiplication without any antifungal and antibacterial agent. Explants were subcultured once in two weeks to fresh respective medium.

\section{Elongation and induction of roots}

Multiplied shoots were separated and inoculated individually on WPM with $0.88 \mu \mathrm{M}$ BAP for elongation. For in vitro root induction, shoots with $4.4-5 \mathrm{~cm}$ height were transferred to half strength WPM macro salts liquid medium fortified with IBA $(2.45-4.90 \mu \mathrm{M})$ and $1 \%$ sucrose for $48 \mathrm{hrs}$, and then shoots were shifted to half strength plain WPM with $1 \%$ sucrose and solidified with $0.2 \%$ phytagel (Sigma, USA). After induction of roots in 6 weeks, plantlets were hardened in pots containing a mixture of sterilized soil and sand (1:1) and maintained in controlled growth chamber conditions $\left(25 \pm 2{ }^{\circ} \mathrm{C}\right.$, 16-h photoperiod, $80 \%$ relative humidity and irradiance of $50 \mu \mathrm{mol} \mathrm{m}$ $2 \mathrm{~s}-1)$.

\section{Ex vitro rooting}

In vitro raised shoots of $G$. indica were also tested for ex vitro rooting response. The shoots were treated with aqueous solution containing IAA (342 and $684 \mu \mathrm{M}$ ) and IBA (295 and 588 $\mu \mathrm{M})$ for $2 \mathrm{hrs}$, planted in plastic pots containing sand and coco 
peat (1:1) and covered with polythene bags to minimize loss of moisture and maintain high humidity. Pots were maintained at 25 $\pm 1^{\circ} \mathrm{C}$ in $24 \mathrm{hrs}$ light photoperiod with watering after every 7 days. The established plants were transferred to greenhouse.

\section{Statistical Analysis}

For statistical analysis, analysis of variance (ANOVA) was done by completely randomized block design (CRBD) using Agrobase 99 software for the experiments and the angular transformation values derived as per Snedecor and Cochran [25].

\section{RESULTS AND DISCUSSIONS}

G. indica being woody tree species harbors high microflora on the surfaces as well as endophytes. This was quite evident by the high percentage of microbial contamination during establishment of sterile cultures. Endogenous and/or surface contamination was the main factors limiting culture establishment. Ten to $70 \%$ of inoculated explants were observed contaminated was after fourth day of culture initiation. Beside contamination, another limiting factor in culture establishment was browning of explants. Like most of the different species of genus Garcinia, $G$. indica is also rich in phenolic compounds which can be attributed to the browning of in vitro cultures. When inoculated on WPM, latex like secretions were observed that resulted the browning of the explants and adjacent medium. The explants which did not contaminate turned brown and subsequently did not survive. Thus, the initial responses observed were tissue browning and contamination along with bud growth and shoot elongation. Similar limitations due to microbial contamination and browning in micropropagation have been observed by Diaz-Sala et al. [26], $\mathrm{Yu}$ and Reed [27] and Nas et al. [28].

For the establishment of sterile cultures and sprouting, different parameters like effects of different antifungal and antibiotic agents, season of explant collection and type of culture vessel used were studied.

\section{Effect of antimicrobial agents}

To avoid the contamination, antifungal agent Bavistin and and antibacterial agents Cefotaxim were tested. These antimicrobial agents were chosen based on some initial experiments done. WPM containing $8.87 \mu \mathrm{M}$ BAP with Bavistin $75 \mathrm{mg} / \mathrm{L}$ and Cefotaxim $400 \mathrm{mg} / \mathrm{L}$ resulted maximum $86 \%$ sterile cultures (Table1).

The supplementation of media with Plant Preservative Mixture (PPM) reduced the sterility to 52.5-62.5\% and moreover these explants turned brown after sprouting. Thus in comparison to MG/L, supplementation of media with Bavistin and Cefotaxime was found more effective for establishment of sterile cultures. Also sterile buds on Bavistin + Cefotaxim containing media were healthy (Table 1). Previously, Bavistin in the culture medium was reported to reduce fungal contamination in Litchi [29]. Likewise, Likewise, Cefotaxime was found to be effective in controlling bacterial growth in plant tissue cultures of Chrysanthemum [30], Lycopersicon [31] Cucumber [32] etc. Therefore, in this present study, this antibiotic was used to raise microbe free culture. Niedz (1998) reported that PPM at $0.2 \%$ could prevent post culture contamination in plant culture vessels [33]. Babaoglu and Yorgancilar (2000) reported similar observations in the regeneration of salad burnet [34] while PPM was used to establish axenic cultures in wych elm [35]. However, in our study, $75 \mathrm{mg} / \mathrm{L}$ Bavistin and $400 \mathrm{mg} / \mathrm{L}$ Cefotaxim were found most optimum for establishment of sterile $G$. indica cultures.

Table 1: Effect of antifungal antibiotic and additive agents on control of contamination in $G$, indica.

\begin{tabular}{|c|c|c|c|c|c|}
\hline \multirow[t]{2}{*}{ Medium } & \multicolumn{2}{|c|}{ Agents } & Additive & \multirow{2}{*}{$\begin{array}{l}\% \\
\text { Sterility }\end{array}$} & \multirow{2}{*}{$\begin{array}{l}\% \\
\text { Contamination }\end{array}$} \\
\hline & $\begin{array}{l}\text { Bavistin } \\
(\mathrm{mg} / \mathrm{L})\end{array}$ & $\begin{array}{l}\text { Cefotaxim } \\
(\mathrm{mg} / \mathrm{L})\end{array}$ & $\begin{array}{l}\text { Plant } \\
\text { preservative } \\
\text { Mixture }(\mathrm{ml})\end{array}$ & & \\
\hline & 75 & 0 & 0 & 42.5 & 57.5 \\
\hline WPM & 75 & 300 & 0 & 30 & 70 \\
\hline+ & 75 & 400 & 0 & 68 & 14 \\
\hline $\mathrm{BAP}(8.87 \mu \mathrm{M})$ & 75 & 500 & 0 & 40 & 60 \\
\hline & 0 & 0 & 1 & 52.5 & 47.5 \\
\hline & 0 & 0 & 2 & 62.5 & 37.5 \\
\hline
\end{tabular}

Basal media WPM $+2 \%$ sucrose $+0.7 \%$ agar

\section{Effect of seasonal variation}

The season in which plant material was collected for raising in vitro cultures showed varied response in terms of contamination and bud break. With optimized sterilization procedure described above, the cultures initiated during the months of January - May showed highest bud break and less contamination than those raised in June - November (Table 2). Since the later period coincides with rainy season in India, 100\% explants raised during this season were contaminated. On the contrary, January- May is the pre-fruiting season of the plant which had good response in terms of percent sterility of the cultures. Similar seasonal effect on culture establishment was reported in other tree species such as apple [36], papaya [37], sweet gum [38] and guava [39].

Table 2 - Effect of collection season on establishment of sterile cultures of $G$ indica

\begin{tabular}{|c|c|c|c|c|c|}
\hline \multirow{2}{*}{$\begin{array}{l}\text { Month of } \\
\text { collection } \\
\text { of explant }\end{array}$} & \multirow{2}{*}{$\begin{array}{c}\text { Phynology } \\
\text { of Plant }\end{array}$} & \multicolumn{2}{|c|}{$\begin{array}{l}\text { WPM+ Bavistin } \\
\quad(75 \mathrm{mg} / \mathrm{L})\end{array}$} & \multicolumn{2}{|c|}{$\begin{array}{c}\text { WPM+ Bavistin (75 } \\
\text { mg/L) } \\
+ \text { Cefotaxim }(400 \mathrm{mg} / \mathrm{L})\end{array}$} \\
\hline & & $\begin{array}{c}\% \\
\text { Sterile } \\
\text { cultures }\end{array}$ & $\begin{array}{c}\% \\
\text { Contamination }\end{array}$ & $\begin{array}{c}\% \\
\text { Sterile } \\
\text { cultures }\end{array}$ & $\begin{array}{c}\% \\
\text { Contamination }\end{array}$ \\
\hline January & Flowering & 42.5 & 57.5 & 86 & 14 \\
\hline April & Fruiting & 46 & 55 & 34 & 63 \\
\hline May & Fruiting & 31 & 57.5 & 37 & 61 \\
\hline September & Vegetative & 17.5 & 72 & 13 & 96 \\
\hline November & Vegetative & 8 & 92 & 4 & 96 \\
\hline
\end{tabular}

Data scored after 6-8 days

\section{Effect of culture vessels}

In the present study, the effect of culture vessel on in vitro response was also investigated. High response in tubes than in bottles on WPM media containing $8.87 \mu \mathrm{M}$ BAP was observed. In bottles, the leaves were comparatively small, only partially opened and leaf fall was seen after 4-5 days of incubation. On the 
contrary, the leaves were fully opened and green in tubes. This observed response in tubes might be due to proper exchange of gases and the moisture creating a drier microenvironment for the tissue. On the contrary, the moisture in bottles is trapped and the microenvironment of the culture remains saturated with moisture. Similar influence of culture vessels on growth and development of culture was previously emphasized in the cultures of woody species by McClelland and Smith [40].

\section{Effect of Auxines and cytokinins}

Nodal explants when cultured on WPM with different concentrations of BAP, Kinetin, IBA and IAA alone or in combination, initiated the axillary bud initiation. Shoot sprouting was initiated after 1-2 weeks. Percent response varied with the type of growth regulator used and its concentration. Among the various auxins and cytokinins tested, BAP alone $(8.87 \mu \mathrm{M})$ induced maximum number of explants to initiate shoots (Fig 1b) with $82 \%$ response (Table 3 ). Similar effect of BAP on axillary bud proliferation was observed by previously Martin [41] and Hiregoudar et al. [42]. BAP at higher concentrations not only reduced the number of shoots but also resulted stunted growth of shoots. These results indicated that increase in BAP concentrations above certain level does not support enhancement of $\%$ response. Shoots were incubated on these particular media for 45 days with shifting on fresh media after every 15 days. Addition of kinetin in media could not significantly increase the \% response while addition of $4.60 \mu \mathrm{M}$ kinetin reduced the $\%$ response. Along with BAP and kinetin, addition of IBA and IAA on bud proliferation was also tested. Like kinetin, IBA and IAA also had no significant effect.

Table 3 Effect of different hormones on $\%$ response in $G$, indica.

\begin{tabular}{ccccc}
\hline BAP $(\mu \mathrm{M})$ & Kinetin $(\mu \mathrm{M})$ & IBA $(\mu \mathrm{M})$ & IAA $(\mu \mathrm{M})$ & $\%$ response \\
\hline & & & & \\
4.44 & - & - & - & 79 \\
8.87 & - & - & - & 82 \\
13.32 & - & - & - & 68 \\
17.76 & - & - & - & 62 \\
22.20 & - & - & - & 55 \\
4.44 & 2.32 & - & - & 72 \\
8.87 & 2.32 & - & - & 75 \\
13.32 & 2.32 & - & - & 71 \\
17.76 & 2.32 & - & - & 68 \\
22.20 & 2.32 & - & - & 65 \\
4.44 & 4.64 & - & - & 52 \\
8.87 & 4.64 & - & - & 48 \\
13.32 & 4.64 & - & - & 41 \\
17.76 & 4.64 & - & - & 32 \\
22.20 & 4.64 & - & - & 31 \\
4.44 & 2.32 & 4.90 & - & 21 \\
8.87 & 2.32 & 4.90 & - & 25 \\
13.32 & 2.32 & 4.90 & - & 28 \\
4.44 & 2.32 & - & 2.85 & 31 \\
8.87 & 2.32 & - & 2.85 & 35 \\
13.32 & 2.32 & - & 2.85 & 37 \\
& & & & \\
\hline & & & &
\end{tabular}

\section{Effect of TDZ on multiplication/ multiple shoot induction}

TDZ, is a phenylurea derivative known to exert cytokinin like action. It was reported that exposure of explants to an optimum TDZ supplemented medium followed by the withdrawal of growth regulators effectively triggers shoot multiplication in many plant species such as Psoralea corylifolia [43], Tamarindus indica [44], Saintpaulia ionantha [45], Medicago truncatula Gaertn. cv. Jemalong and Medicago truncatula ssp. Narbonensis [46] and Hibiscus cannabinus [47] etc. On the contrary, cultures continuously grown on TDZ containing media resulted in fasciated and distorted shoots. Deleterious effect of continued incubation in TDZ was reported on growth and multiplication of Cicer arietinum [48] and Rauwolfia tetraphylla [49]. In the view of these reports, $G$. indica tissue was also exposed to WPM media containing TDZ in the range 2.27-4.45 $\mu \mathrm{M}$ with $8.87 \mu \mathrm{M}$ BAP for 45 days with subculture on fresh media after every 15 days. Initiation of multiple shoots was observed after 20 days on media supplemented with TDZ in the range $0.22-4.54 \mu \mathrm{M}$ along with BAP $8.87 \mu \mathrm{M}$. Significantly higher multiplication rate was noted with the combined treatment of $8.87 \mu \mathrm{M}$ BAP and $4.54 \mu \mathrm{M}$ TDZ (significant at $1 \%$ level). With these concentrations of TDZ and BAP, 3-4 shoots with average shoot length of $5.92 \mathrm{~cm}$ were induced after third subculture (Table 4) (Fig $1 \mathrm{c}$ and d).

Table 4: Effect of TDZ on no, of multiple shoot induction and elongation of shoots in nodal explants of $G$, indica

\section{Hormones Number of subculture}

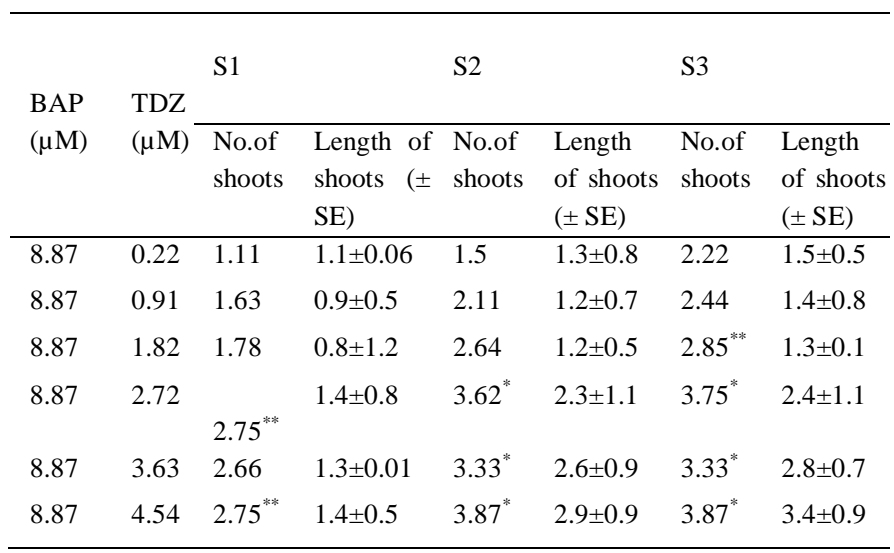

Basal media WPM $+2 \%$ sucrose $+0.7 \%$ agar Values are Mean \pm SE of three experiments. $* * *$ Significant at $5 \%$ and $1 \%$ level respectively

The shoots were maintained by sub-culturing on the same media after 15 days. At every stage of subculture on same media, shoot multiplication was observed. These shoots were observed to elongate further with repeated subculture on respective media. After 40-45 days, these multiple shoots were separated and transferred to fresh media every 15 days interval. This frequent transfer was noted to be essential to prevent defoliation and to maintain culture vigor for sustained shoot growth. Transfer of original explant directly to media supplemented with TDZ in the range $0.22-4.54 \mu \mathrm{M}$ along with BAP $8.87 \mu \mathrm{M}$ did not induce any 

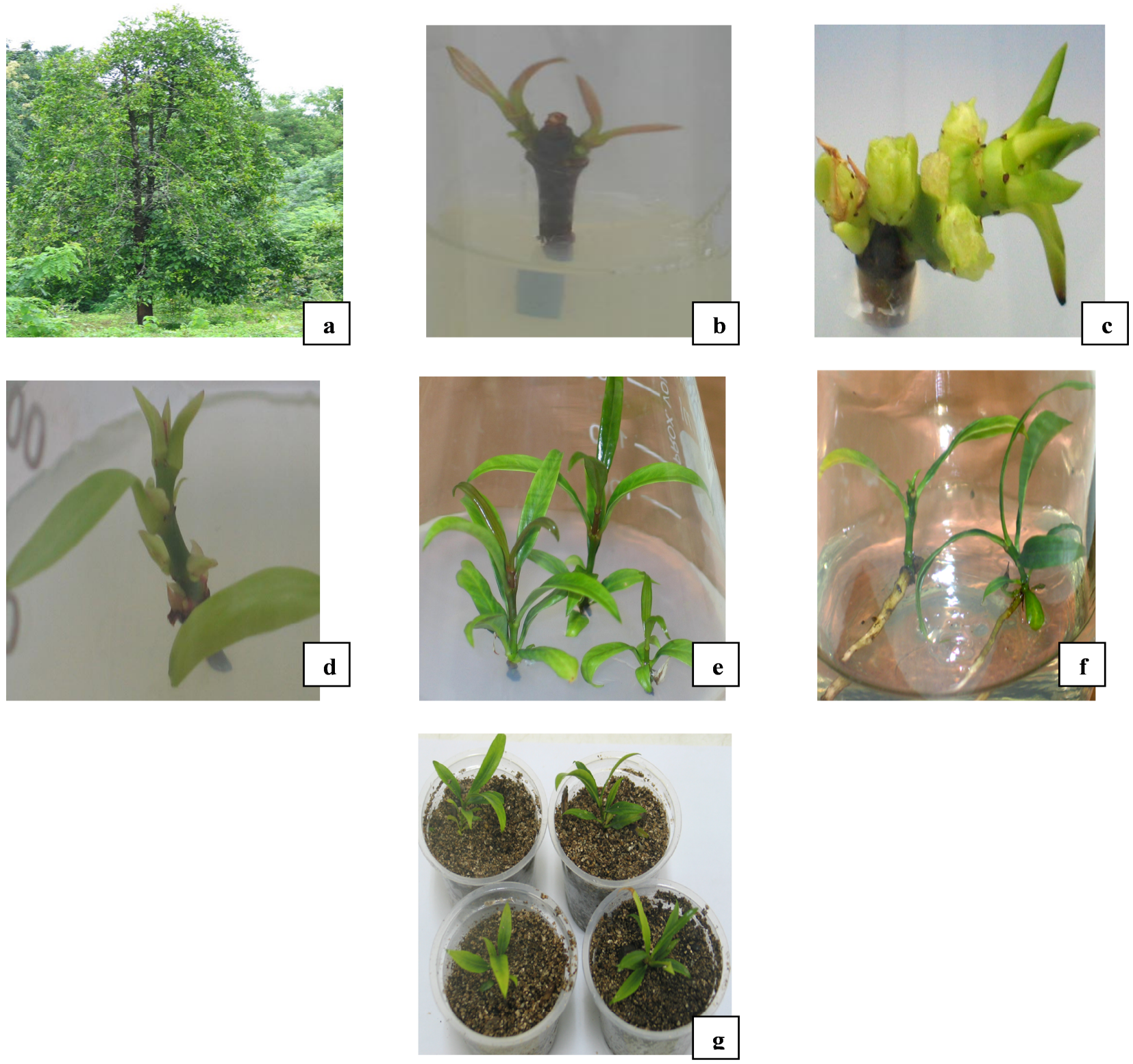

Fig. 1 a. Habitat of $G$. indica. Fig. 1 b .Sprouting of axillary bud on WPM containing $8.87 \mu$ M B AP with $75 \mathrm{mg} / \mathrm{L}$ Bavistin and $300 \mathrm{mg} / \mathrm{L}$ Cefotaxim. Fig. $1 \mathrm{c}$ and d. Multiple shoots induction on WPM media with $8.87 \mu \mathrm{M}$ BAP and $4.54 \mu \mathrm{M}$ TDZ. Fig. 1 e. Elongation of multiple shoots on $0.87 \mu \mathrm{M}$ BAP. Fig. 1 f. Rooting of shoots on WPM media with $4.90 \mu \mathrm{M}$ IBA. Figure 1 g. Hardened plants.

additional multiple shoots. New shoots harvested at each subculture were inoculated individually on same media to obtain further multiplication.

Although the phenomenon of fasciated shoots was previously reported to be associated with the use of TDZ [50]. The regenerated plants produced in this study exhibited neither fascinated shoots nor any other abnormal characters. Thus for micropropagation of $G$. indica, the use of TDZ was found best without any adverse effect.

\section{Induction of in vitro roots}

Shoots when maintained on multiplication media for longer period remained very small and required further elongation step for rooting induction. Therefore WPM with a low BAP $(0.89 \mu \mathrm{M})$ was used for shoot elongation. It was observed that reduced concentration of BAP stimulated shoot elongation. Similar observations wherein reduced BAP concentration resulted shoot elongation were made by Chalupa (1987) in Tila cordat [51]. However higher concentration of BAP was reported to be inhibitory for shoot elongation [52,53]. It was found that shoots elongated to maximum 4.4-5.0 cm length within 15-20 days after their transfer to BAP containing medium (Fig 1e). To check their rooting competence, these shoots were then transferred to WPM containing half strength macro stock, IBA in the range and 2.45$4.90 \mu \mathrm{M})$ and $1 \%$ sucrose without agar for $48 \mathrm{hrs}$. After $48 \mathrm{hr}$., they were shifted to WPM media containing half strength macro 
salts with $1 \%$ sucrose and $0.2 \%$ phytagel without any hormones. Root induction was observed within 20-25 days from the base of shoots at nodal portion (Fig 2). Maximum $63.2 \%$ shoots were observed to induce rooting on WPM supplemented with $4.90 \mu \mathrm{M}$ IBA with an average $3.4 \mathrm{~cm}$ length of shoots. Rooting \% was very less $(10 \%)$ on WPM containing $3.94 \mu \mathrm{M}$ IBA while with $3.44 \mu \mathrm{M}$ IBA, $52.7 \%$ rooting was observed (Fig 1f).

The well developed plantlets were later shifted to potting mixture of sterilized sand and soil (1:1) for acclimatization. Initially these pots were covered with polythene bags for 15 days which then was gradually removed. Acclimatized plants were then transferred to green house, where $70 \%$ survival was achieved.

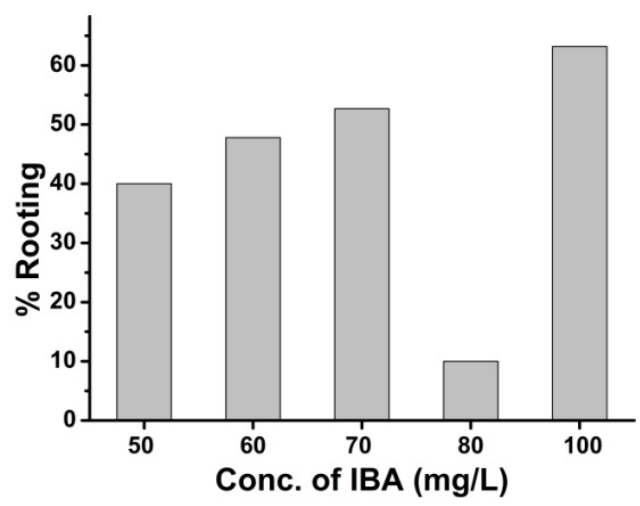

Basal media - WPM $1 \frac{1}{2}$ Macro $+1 \%$ Sucrose

Fig. 2: Effect of different IBA concentrations on in vitro rooting in shoots of G. indica

\section{Ex vitro rooting}

In this study, experiments were also performed to induce the roots to in vitro grown shoots ex vitro. For ex vitro rooting, shoots were dipped in IAA (3.42 and $6.84 \mu \mathrm{M})$ and IBA solutions ( 2.95 and $5.88 \mu \mathrm{M}$ ) for $2 \mathrm{hrs}$ and then shifted to potting mixture containing sterilized sand and cocopeat $(1: 1)$, and covered with polythene bags to maintain moisture. Forty percent shoots induced ex vitro rooting to IAA $(3.42 \mu \mathrm{M})$ treated shoots within 50-60 days (Table 5). Such ex vitro induced rooted shoots in pots were maintained in hardening room with controlled temperature $\left(25^{\circ} \mathrm{C}\right)$ and continuous light. Plants were watered after every 8 days and were then shifted to greenhouse where $60 \%$ plantlets were observed survived and healthy (Fig $1 \mathrm{~g}$ ).

These results demonstrated the feasibility of the application of tissue culture technique for raising female and elite trees of $G$. indica - a tree of great economic importance. Generally woody plants are known to be recalcitrant to in vitro regeneration and multiplication. In the view of this fact, the rate of multiplication in $G$. indica was also low since the explants were derived from mature woody trees. Unlike for other horticultural plants, the use of tissue culture techniques for the propagation of tree species like $G$. Indica was beset with very special problems. Some of these include the physiological state of the material (Juvenile/ mature phases), general recalcitrant response of the explants vis a vis medium, inadequate rooting of the regenerated shoots and the associated problems of poor transfer ratio of established plants into soil. Nevertheless, micropropagation using tissue culture is the best and widely used method for clonal propagation of selected clones. Previously, many plant species of medicinal importance such as Baliospermum montanum [54,55], Spilanthes acmella [56], Curculigo orchioides [57], Azadirachta indica [58] etc. were successfully clonally propagated.

Table 5: Effect of different auxin concentrations on ex vitro rooting

Auxin concentration

$\%$ rooting

$\begin{array}{ll}\text { IBA }(2.95 \mu \mathrm{M}) & 10 \\ \text { IBA }(5.88 \mu \mathrm{M}) & 10 \\ \text { IAA }(3.42 \mu \mathrm{M}) & 40 \\ \text { IAA }(6.84 \mu \mathrm{M}) & 20\end{array}$

\section{CONCLUSION}

This study reporting the clonal method of propagation of G. indica, a economically important horticultural tree species with high medicinal importance, offers a great potential for mass multiplication of female plants for large scale plantation. Along with this, the elite female plants having maximum \% HCA can also be propagated by this method. Using the method reported in this study, 4-5 plants from single apical bud can be produced within 130-135 days through in vitro rooting and in 165-170 days through ex vitro rooting.

\section{ACKNOWLEDGEMENTS}

CSIR, New Delhi is thankfully acknowledged for Research Fellowship to Swapna Deodhar.

\section{REFERENCES}

1. Shara M, Ohia SE, Schmidt RE, Yasmin T, Zerdetta-Smith A, Kincaid A, Bagchi M, Chatterjee A, Bagachi D. and Stohs SJ. Physio-chemical properties of a novel (-) Hydroxycitric acid extract and its effect on body weight selected organ weight hepatic lipid peroxidation and DNA fragmentation hematology and clinical chemistry and histopathological changes over a period of 90 days. Molecular and Cellular Biochemistry. 2004; 260(1): 171-186.

2. Preuss HG, Bagchi D, Bagchi M, Rao CVS, Satyanarayana S and Dey DK. Efficiency of novel natural extract of (-) Hydroxycitric acid (HCA-SX) and a combination of HCA-SX niacin bound chromium and Gymnema sylvestre extract in weight management in human volunteers: A pilot study, Nutrition Research. 2004; 24 : 55-58.

3. Jena S, Jayaprakasha GK, Singh P, and Sakariah KK. Chemistry and Biochemistry of (-) Hydroxy Citric Acid, Journal of Agriculture Food Chemistry. 2002; 50(1): 10-22.

4. Watson JA, Fang M, and Lowenstin JM. Tricarbollylate and hydrooxycitrate substrate and inhibitors of ATP: citrate oxaloacetate lyase, Archive of Biochemistry and Biophysics. 1969: 135: 209-217.

5. Reddy SY. and Prabhakar JV. Cocoa butter extenders from kokum (Garcinia indica) and phulwara (Madhuca butyraceae) butter, J,Ann, Oil Chem, Soc. 1994; 71: 217-219.

6. Sundaram BM, Gopalkrishnan C, Subramanian S. and Shankaranarayan D. Anti microbial activity of Garcinia mangostana. 1983; Planta Medica 4: 59-60, 
7. Iwu MM, Igboko OA, Okunji CO. and Tempests MS, Anti diabetic and aldose reductase activities of bioflavanones of Garcinia kola. J, Pharm, Pharmacol. 1990; 42: 290-292.

8. Chen S, Wan M., Lok BN. Active constituents against HIV-1 protease from Garcinia mangostana, Planta Med. 1996; 62: 381-82.

9. George GL, Lakshmanan R, Mathew KM, and Rao TS. Review of research in kokum camboge and relates species, Journal of Spices and Aromatic Crops. 2002; 11: 1-12.

10. Malik SK, Chaudhary R, Abraham Z. Desiccation-freezing sensitivity and longevity in seeds of Garcinia indica $G$, combogia and $G$, xanthochymus, Seed Science Technology. 2005; 33 (2).

11. Haldankar PM, Salvi MJ, Joshi GD, and Patil JL. Factors influencing softwood grafting in kokam (Garcinia indica Choisy), Indian Cocoa Arecanut Spices Journal. 1993; 17: 15-18.

12. Nawala RN, Karmarkar MS. Softwood grafting technique for rapid multiplication of high yielding clones in kokum (Garcinia indica Choisy). Indian Cocoa Arecanut Spices Journal. 1997;21: 76-77.

13. Rajasekharan PE, and Ganeshan S. Conservation of medicinal plant biodiversity - an Indian perspective. J Med Arom Plants. 2002; 24: 132.

14. Engelmann F. Importance of cryopreservation for the conservation of plant genetic resources, In Engelmann F Takagi $\mathrm{H}$ (Eds) Cryopreservation of Tropical Plant germplasm Current research progress and Application, JIRCAS Tsukuba Japan/IPGRI Rome Italy. 2000; 8-20.

15. Normah MN, Nor-Azza AB. and Alidun R. Factors affecting invitro shoot proliferation and exvitro estsblishment of mangosteen. Plant Cell Tissue Org, Cult. 1995; 43: 291-294,

16. Goh C, Lakshmanan P. and Loh C. High frequency direct shoot bud regeneration from excised leaves of mangosteen ( Garcinia mangostana L,). Plant Sci. 1994; 101: 173-180,

17. Te-Chato S. and Lim M. Plant regeneration of mangosteen via nodular callus formation. Plant Cell Tissue Org, Cult. 1999; 59: 89-93.

18. Thengane SR, Deodhar SR, Bhosle SV. and Rawal SK. Repetitive somatic embryogenesis and plant regeneration in Garcinia indica Choiss, In vitro cellular and developmental biology - Plant. 2006; 42: 256-261.

19. Deodhar SR, Thengane RJ, and Thengane SR. De novo shoot regeneration from root cultures of Garcinia indica Choiss. Indian Journal of Experimental Biology. 2008; 46: 482-486.

20. Malik SK, Chaudhary R. and Kalia RJ. Rapid in vitro multiplication and conservation of Garcinia indica: A tropical medicinal tree species. Scientia Horticulture. 2005; 106: 539-553.

21. Kulkarni M. and Deodhar M. In vitro regeneration and hydroxycitric acid production in tissue culture of Garcinia indica Choiss, Indian J, Biotech. 2002; I: 301-304.

22. Deshpande RS, Chavan SS. and Dhonuske BL. In-vitro shoot regeneration in kokum (Garcinia indica Choiss). Annals of Plant Physiology. 1999; 13: 31-34.

23. Mathew KM, Rao YS, Kuruvilla KM, Lakshmanan R, George GL, Madhusoodanan KJ. and Potty SN. Multiple shoot regeneration in kokum and camboge. Journal of spices and aromatic crops. 2001; 10: 151-152.

24. Loyd C. and McCown B. Commercially feasible micropropagation of mountain laurel Kalmia latifolia by use of shoot tip culture. Int, Plant Propagation Soc, Proc. 1980; 30: 421-427.

25. Snedecor GW. and Cochran WG. 1967; Statistical methods Mohan Primlani Oxford and IBH publishing Co, New Delhi 569571.

26. Diaz-Sala C, Rey M, and Rodriguez R. In vitro establishment of cyclonal chain from nodal segments and apical buds of adult hazel (Corylus avellana L,). Plant Cell Tissue Organ culture. 1990; 23: 151-157.

27. Yu X. and Reed BM. A micropropagation system for hazelnut (Corylus avellana L,), HortScience. 1995; 30: 120-123.

28. Nas Mehmet Nuri. Inclusion of polyamines in the medium improves shoot elongation in hazelnut (Corylus avellana $\mathrm{L}$,) Micropropagation, Turk J Agri For. 2004; 28: 189-194.

29. Das DK, Shiva Prakash N. and Bhalla-Sarin N. Multiple shoot induction and plant regeneration in litchi (Litchi chinensis Sonn,). Plant Cell Reports. 1999; 18: 691-695.

30. Jaime A, Teixeira and Da Silva, Tissue culture of Chrysanthemum: A review. Propagation of ornamental plants. 2003; 3(2): 23-29.

31. Raj SK, Singh R, Pandey SK, and Singh BP. Agrobacterium mediated tomato transformation and regeneration of transgenic lines expressing tomato leaf curl virus coat protein gene for resistance against TLCV infection, Research communications. Current Science. 2005; 10(88): 1674-1679.

32. Sapountzakis G. and Tsaftaris AS In vitro regeneration and genetic transformation of parthenocarpic cucumber hybrid ISHS Acta Horticulturae. 2002; 579: II Balkan Symposium on Vegetables and Potatoes.

33. Niedz RP. Using isothiazolone biocides to control microbial and fungal contaminants in plant tissue cultures. Hort Technology. 1998; 8: 598-601.

34. Babaoglu M. and Yorgancilar M. TDZ-specific plant regeneration in salad burnet. Plant Cell Tissue Organ Culture. 2000; 440: 31-34.

35. Biroscikova M, Spisakova K, Liptak S, Pichler V. and Durkovie J. Micropropagation of mature wych elm (Ulmus glabra Huds,). Plant Cell Reports. 2004; 22: 640-644.

36. Hutchinson JF. Factors affecting shoot proliferation and root initiation in organ culture of apple 'Northern Spy'. Scientia Horticulture. 1984; 22: 347-358.

37. Litz RE. and Conover RA. Effect of sex type season and other factors on in vitro establishment and culture of Carica papaya $\mathrm{L}$, explant. Journal of American society Horticulture Science. 1981; 106, 792-794.

38. Sutter EG. and Barker PB. In vitro propagation of mature Liquidambar atyraciflua. Plant Cell Tissue Organ Cultur. 1987; 5: 13-21,

39. Amin MN. and Jaiswal VS. Rapid clonal propagation of Guava through in vitro shoot proliferation on nodal explants of mature trees. Plant Cell Tissue Organ Culture. 1987; 9: 235-243,

40. McClelland Smith MAL. Vessel type Closure and explant orientation influence in vitro performance of five woody species. Horticulture Science. 1990; 25: 797-800.

41. Martin KP. Raid in vitro multiplication and ex vitro rooting of Rotula aquatica Lour a rare rheophytic woody medicinal plant. 2003; Plant Cell reports. 21: 415-420.

42. Hiregoudar LV, Murthy HN, Bhat JG, Nayeem A, Hema BP, Hahn EJ. and Paek KY. Rapid clonal propagation of Vitex trifolia, Biologia plantarum. 2006; 50(2): 291-294.

43. Faisal M. and Anis M. Thidiazuron induced high frequency axillary shoot multiplication in Psoralea corylifolia. Bilogia Plantarum. 2006; 50: 437-440.

44. Mehta UJ, Sahasrabudhe N. and Hazra S. Thidiazuron-induced morphogenesis in tamarind seedlings. In Vitro Cellular \& Developmental Biology - Plant. 2005; 41(3): 240-243.

45. Mithila J, Hall JC, Victor JMR. and Saxena PK. Thidiazuron induces shoot organogenesis at low concentrations and somatic embryogenesis at high concentrations on leaf and petiole explants of African violet (Saintpaulia ionantha Wendl,). Plant Cell Reports. 2003; 21: 408-414. 
46. Neves LO, Tomaz L. and Fevereiro MPS. Micropropagation of Medicago truncatula Gaertn, cv, Jemalong and Medicago truncatula ssp, Narbonensis. Plant Cell Tissue and Organ Culture. 2001; 67 (1): 81-84.

47. Srivatanakul M, Park S, Sanders J, Salas M. and Smith R. Multiple bud regeneration of kenaf (Hibiscus cannabinus L,) from bud apex culture system, Plant Cell Reports. 2000; 19(12): $1165-1170$

48. Murthy BNS, Victor J, Singh RP, Fletcher RA. and Saxena PK. In vitro regeneration of chickpea (Cicer arietinum L,): stimulation of direct organogenesis and somatic embryogenesis by Thidiazuron. Plant Growth Regulators. 1996; 19: 233-240.

49. Faisal M, Ahmad N. and Anis M. Shoot multiplication in Rauvolfia tetraphylla L, using thidiazuron. Plant Cell Tissue Organ Culture. 2005; 80: 187-190.

50. Huetteman CA. and Preece JE. Thidiazuron: a potent cytokinin for woody plant cell tissue culture. Plant Cell Tissue Organ Culture. 1993; 33: 105-121.

51. Chalupa V. Effect of Benzylaminopurine and Thidiazuron on in vitro shoot proliferation of Tilia cordata MILL, Sorbus aucuparia L, and Robinia pseudoacacia L. Biologia Plantarum. 1987; 29(6): 425-429.

52. Fukui $\mathrm{H}$, Kano $\mathrm{T}$, Takeuch $\mathrm{S}$. and Nakamura $\mathrm{M}$. In vitro growth of Japanese persimmon (Diospyros kaki Thunb,) seedling plants. Res, Bull, Fac, Agr, Gifu, Uni. 1987; 52: 25-30.

53. Bahrany Abdulaziz Swing. Effect of phytohormones on in vitro shoot multiplication and rooting of lime Citrus aurantifolia (Christm,). Scientia Horticulturae. 2002; 95(4): 285-295.
54. Sasikumar S, Raveendar S, Premkumar A, Ignacimuthu S. and Agastian P. Micropropagation of Baliospermum montanum (Willd) Muell, Arg, - Athreatened medicinal plant. Indian J of Biotechnology. 2009; 8: 223-226.

55. George S, Geetha SP and Balachandran I. Micropropagation of Baliospermum montanum (Willd) Muell - Arg - A red listed medicinal plant. J of plant Sciences. 2008; 3(1): 111-115.

56. Haw AB. and Keng CL. Micropropagation of Spilanthes acmella L, a bio-insecticide plant through proliferation of multiple shoots. J Appl Hortic. 2003; 5(2): 65-68.

57. Wala BB. and Jasrai YT. Micropropagation of an endangered medicinal plant: Curculigo orchioides Gaertn. Plant Tissue Culture. 2003; 13: 13-19.

58. Joshi MS. and Thengane SR. In vitro propagation of Azadirachta indica A, Juss, (neem) by shoot proliferation. Indian Journal of Experimental Biology. 1996; 34: 480-482

\section{How to cite this article:}

Swapna Deodhar, Kiran Pawar, Nitasha Singh, Thengane RJ, Thengane SR. Clonal propagation of female plants of Garcinia indica Choiss: a tree species of high medicinal value. J App Biol Biotech. 2014; 2 (06): 018-025. 